\title{
$\mathrm{ZnO}$ の焼結における雾囲気酸素圧の影響
}

\author{
小 松 和 蔵・守 吉 佑 介 \\ (東京工業大学)
}

\section{The effect of oxygen pressure on sintering of zinc oxide}

\author{
By \\ Wazo KOMATSU and Yusuke MORIYOSHI \\ (Faculty of Engineering, Tokyo Institute of Technology)
}

\begin{abstract}
The effect of oxygen pressure on sintering of zinc oxide has been investigated by measuring isothermal shrinkage of compacts at $750^{\circ}$ and $850^{\circ} \mathrm{C}$. The sinterability was proportional to $P_{\mathrm{O}_{2}}{ }^{-1 / 5.4}$ at $750^{\circ} \mathrm{C}$ in oxygen atomsphere $\left(P_{\mathrm{O}_{2}}>2.5 \times 10^{-2}\right.$ torr $)$ and to $P_{\mathrm{O}_{2}}{ }^{-1 / 5,4}$ at $850^{\circ} \mathrm{C}$ in $P_{\mathrm{O}_{2}}>3 \times 10^{-3}$ torr. The result indicates that the sintering process is controlled by diffusional transfer of interstitial zinc ions. In the lower oxygen pressure, the sintering rate was independent of the pressure. This result was explained by the cooperation of two different mechanisms, i.e., diffusional transfer of interstitial zinc ions and lattice formation process between interstitial zinc and oxygen.
\end{abstract}

[Received June 7, 1971]

\section{1. 緒言}

$\mathrm{ZnO}$ の焼結における雾囲気の影響が 試料によってま ちまちの結果になることが Roberts ら゙の研究で知られ ている.この原因は $\mathrm{ZnO}$ の燒結性が出発物質中の不純 物などによってきわめて敏感に影響されるためである う.したがって $\mathrm{ZnO}$ の燒結機構を解明するためには高 純度の試料を多量につくり, 不純物の影響, 雾囲気の影 響などについて順次系統的に研究する必要がある。この ような観点からわれわれは, 高純度の $\mathrm{ZnO}$ に不純物を

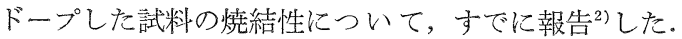

その研究に扔いては $\mathrm{ZnO}$ の焼結性が格子間亜鉛イオ ンの物質移動によって支配されることを格子欠陷理論の 立場から，すなわち，低执よび高原子価の酸化物のドー ピングによって増加むしくは減少する格子間亜鉛イオン の濃度と焼結性との関連性加ら推論した. 格子間亜鉛イ オンの濃度は雾囲気酸素圧と平衡関係にあるので，この 推論をさらに明確にするため広い範囲に雾囲気酸素圧を 変えて研究した。

$$
\begin{aligned}
& \mathrm{ZnO} \text { では (1), (2) 式で示す解離平衡が成立し, } \\
& \mathrm{ZnO} \rightleftarrows \mathrm{Zn}^{\circ}+\ominus+1 / 2 \mathrm{O}_{2} \\
& \mathrm{ZnO} \rightleftarrows \mathrm{Zn}^{\circ \circ}+2 \ominus+1 / 2 \mathrm{O}_{2}
\end{aligned}
$$

（1）式の場合，質量作用の法則から

$$
X_{Z n^{\circ}} \times X_{\ominus} \cdot P_{\mathrm{O}_{2}}{ }^{1 / 2}=K
$$

がえられる。ここで $X_{Z n^{\circ}}$ ，および $X_{\ominus}$ はそれぞれ格子 間业鉛イオンおよび自由電子の濃度，KM平衡定数を示
す. $X_{Z n^{\circ}}=X_{\ominus}$ であるから，格子間亜鉛イオン濃度は酸 素圧 $P_{\mathrm{O}_{2}}$ と (4) 式の関係に岁る。

$$
X_{Z n^{\circ}}=\text { const } \cdot P_{\mathrm{O}_{2}}{ }^{-1 / 4}
$$

同様の手続で (2) 式の解離平衡では,

$$
X_{Z n^{\circ 0}}=\text { const } \cdot P_{\mathrm{O}_{2}}{ }^{-1 / 6}
$$

(4), (5) 式から, もし $\mathrm{ZnO}$ の焼結性が格子間亜鉛イオ ンの物質移動によって支配されるなら, その焼結性は酸 素圧に対してー-1/4 乘ないし $-1 / 6$ 乗に比例すると考え られる ${ }^{32}$.

\section{2. 実験}

\section{1 試料}

市販特級塩基性炭酸亜鉛 $\left(5 \mathrm{ZnO} \cdot 2 \mathrm{CO}_{2} \cdot 4 \mathrm{H}_{2} \mathrm{O}\right)$ を真 空中 $\left(10^{-3}\right.$ torr $) 300^{\circ} \mathrm{C}, 30$ 時間处理して $\mathrm{ZnO}$ をつく った.これを $500^{\circ} \mathrm{C}, 3$ 時間空気中で処理し, さらに $700^{\circ} \mathrm{C}$ で 1.5 時間空気中で処理して試料とした。電子 顕微鏡観察によれば粒径は $0.2 \mu$ 以下で形状は丸味をお びた球形に近いものであった。

錠剤の作製にはプレスを用い， $\mathrm{ZnO}$ 試料約 $800 \mathrm{mg}$ に $1 \mathrm{t} / \mathrm{cm}^{2}$ の荷重を加え直径 $10 \mathrm{~mm}$, 厚さ $4 \mathrm{~mm}$ の錠 剂に成形した。焼結前の 錠剤の 密度は 理論密度のほぼ 50\%であった。この錠剤を燒結における収縮率測定と $950^{\circ} \mathrm{C}, 5$ 時間空気中で焼結して電気伝導度測定の試料 とした.

\section{2 実験方法}




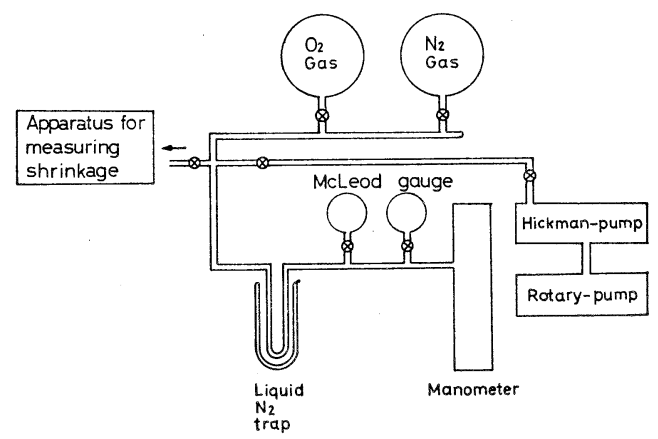

Fig. 1. Apparatus for measuring shrinkage.

収縮の測定には差動偏位測定器を用いて行なったが，

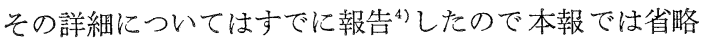
する。その収縮測定装置を図-1 に示した真空系に接続 して，750 と $850^{\circ} \mathrm{C}$ とにおける錠剤試料の収縮をいる いろな酸素圧のもとで測定した. 焼結を行なら前に試料 の吸着水および吸着ガスの除去のため，常温において $10^{-6}$ torr で 30 分間排気処理を行なった. その後, 所定 の酸素を導入した.

加熱は次のように行なった．所定温度に到達する時間 をはやくするため燒結温度より約 $300^{\circ} \mathrm{C}$ 低い温度で予 備加熱を行ない，その後電気炉の所定温度の部分に導入 した．所定温度に達するまでにおこる収縮は無視できる ほど小さかった。また所定温度に達するまでの時間は 2 分程度であった．温度の測定には白金一白金・ロジウム (13\%) 熱電対を用い温度は所定温度に対して $\pm 1^{\circ} \mathrm{C} に$ 保った。収縮の測定はレコーダーにより自動記録した。 収縮の基準になる初期の厚さ $L_{0}$ には温度が所定温度に 到達したときの厚さを用いた.この厚さはマイクロメー ターにより常温で測定した值を基準として，所定温度に 到達したときのレコーダーの読みから求めた。真空度の 測定には回転マクレオード真空計および水銀マノメータ 一を使用した。低圧実験の場合，水銀蒸気を除去するた め液体窒素トラップを用いた。

\section{3 電気伝導度測定}

$\mathrm{ZnO}$ において格子間监鉛イオン濃度および自由電子 濃度と䨌囲気酸素圧との平衡関係についてはすでにのべ た。したがって電気伝導度を測定することによって，そ れらに関する知見をうることができる，測定はすでに報 告 ${ }^{5}$ したように2 端子法でおこなった. 回路の電源には 乾電池を用い, 錠剤はおもりの重量により白金電極の上 下よりはさみ固定した。測定には試料の抵抗の時間変化 を予備実験によりしらべ, 一定温度平衡到達後に測定し た.

\section{3. 実験結果と考察}

焼結における雾囲気の影響老研究する場合, 雾囲気酸 素と被焼結体との平衡がごく短時間のらちに達成される

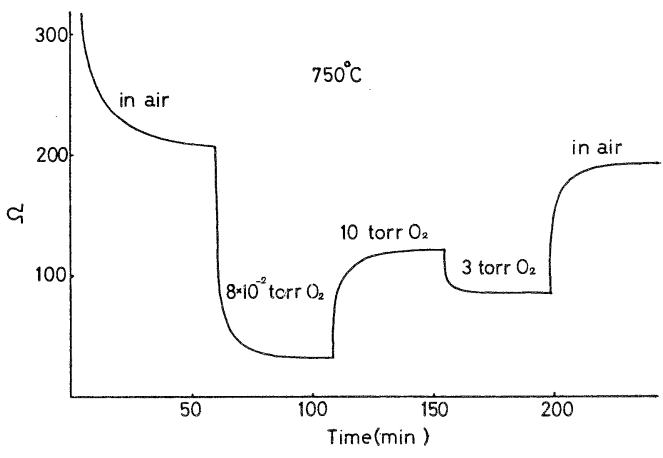

Fig. 2. Responsibility of resistance of $\mathrm{ZnO}$ compact to oxygen pressure.

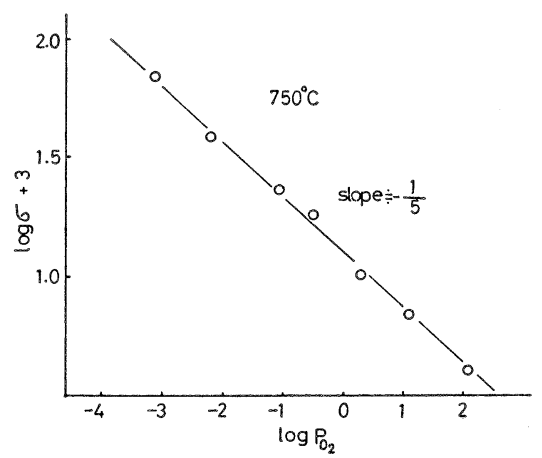

Fig. 3. Effect of oxygen pressure on conductivity of $\mathrm{ZnO}$.

のか，平衡に達するまでの時間が長く，その過程が焼結 過程と平行して同時におこるのかが問題となる。これを 調べるために雾囲気酸素圧を変えた場合の電気伝導度 $\sigma$ $\left(\Omega^{-1} \mathrm{~cm}^{-1}\right)$ の時間変化を測定した。

図-2 には未焼結 $\mathrm{ZnO}$ 錠剤を $750^{\circ} \mathrm{C}$ に制御した伝導 度測定セル中に導入し, 雾囲気圧をいろいろに変化させ た場合の抵抗值と時間との関係を示した. 初めの大きな 抵抗值の減少は錠剤の温度上昇ならびに焼結によるもの と考えられる。図からわかるよらに雾囲気圧を変えたと きの抵抗值は急激に変化し, 短時間にほぼ一定值に収束 することがわかる。このことから $\mathrm{ZnO}$ と雰囲気酸素と の平衡がすみやかに達成され，格子間亜鉛イオンの濃度 が雰囲気酸素と平衡状態を保ちながら焼結が進行すると 推論した.

$750^{\circ} \mathrm{C}$ における伝導度と酸素圧との関係の対数プロッ 卜を図-3 に示した，良く直線上にのることがわかり， その勾配は $-1 / 5$, つまりその酸素圧依存性は $-1 / 5$ に 比例して変化することがわかる．この值は緒言でのべた (1)，(2) 式で示される酸素圧依存性のちょらど中間の值 であった。つまり（1），(2) 式が同時におこっていると 考えられる.

$850^{\circ} \mathrm{C}$ についても同様の測定を試みたが，酸素圧の低 い領域では試料の電気抵抗が非常に小さくなり, 使用し 


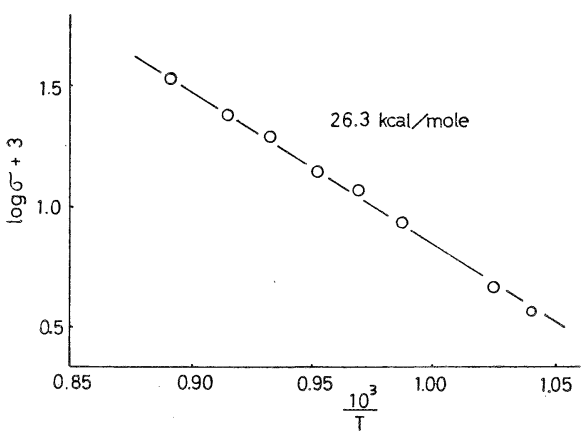

Fig. 4. Conductivity of $\mathrm{ZnO}$ as a function of temperture.

た装置では十分正確に測定できなかった。酸素圧が十分 高いと電気抵抗が大きく測定可能であるので $685^{\circ} \sim 850$ ${ }^{\circ} \mathrm{C}$ の温度範囲, 40 torr $\mathrm{O}_{2}$ 中で電気伝導度の温度依存 性を測定した（図-4）。図からわかるように測定温度範 囲で直線関係が成立する．このことは $850^{\circ} \mathrm{C}$ でも $750^{\circ} \mathrm{C}$ の場合と同様の酸素圧依存性を示すと考えられる。四の 直線の勾配からえられる見脚けの活性化エネルギーは $26.3 \mathrm{kcal} / \mathrm{mol}$ であった。この值は $600^{\circ} \mathrm{K}$ 以上の温度 で $16.4 \mathrm{kcal} / \mathrm{mol}$ となると報告している $\mathrm{Hauffe}^{6)}$ の值 より大きく，この差異が試料および処理条件の違いによ るものかどらか明確でない。

雾囲気酸素纴をいろいろに変えた場合の $750^{\circ} \mathrm{C}$ 抢よ び $850^{\circ} \mathrm{C}$ における収縮率と時間との関係を図-5，6に 示した. $750^{\circ} \mathrm{C}, 850^{\circ} \mathrm{C}$ いずれの場合も曲線の形は似て おり，どちらも酸素圧が低くなるほど収縮率が大きく焼 結性が良くなってゆくことがわかる． $750^{\circ} \mathrm{C}$ での酸素压 依存性は $2.5 \times 10^{-2}$ torr $\mathrm{O}_{2}$ より低い酸素圧でほとんど

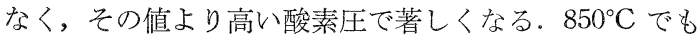
同様の傾向があるが，これら焼結性と酸素圧依存性に関 する考察は後に述べる。

燒結に㧍ける酸素圧依存性を定量的に検討するために は，収縮率のデーターがどのような速度式でよくあらわ されるかを十分検討する必要がある。われわれは $\mathrm{ZnO}$ 錠剤の初期焼結の研究に括いて，収縮率測定と平行させ

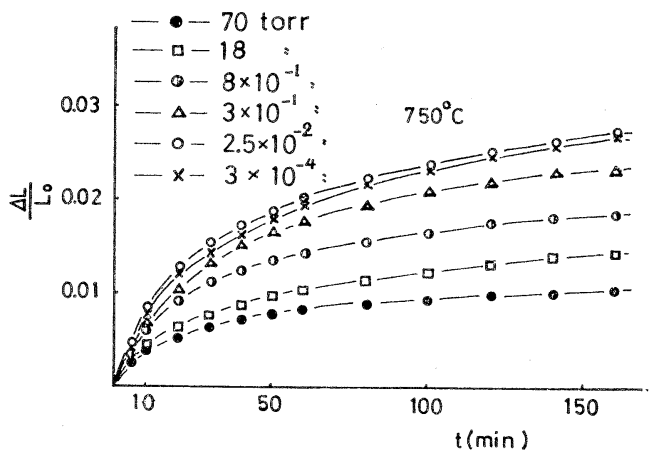

Fig. 5. Linear plots of shrinkage for sintering of $\mathrm{ZnO}$ compacts at various oxygen pressures.

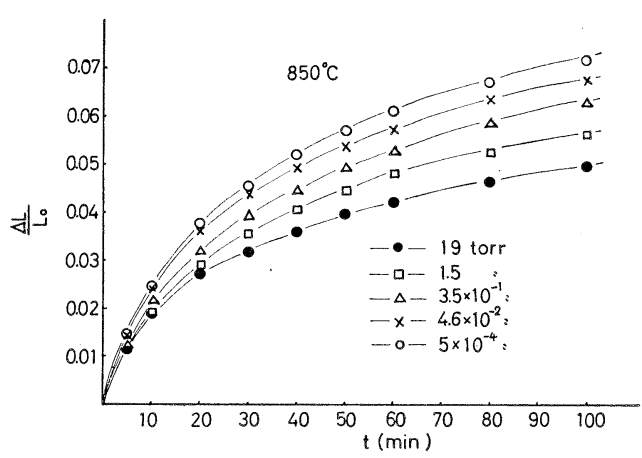

Fig. 6. Linear plots of shrinkage for sintering of $\mathrm{ZnO}$ compacts at various oxygen pressures.

て，錠剤断面の電子顕微鏡観察をおこなったそその結 果, いわゆる両対数プロットが直線からズレる部分に著 しい粒成長があることを確認した。そして粒成長を考慮 して新しい速度式およびその良い近似 (6) 式を提出し4， 錠剤焼結のデーターが初期から直線であらわされること を示した。

$$
\frac{\Delta L}{L_{0}}=K^{0.31} \times \frac{t^{0.31}}{\left(1+k t^{1 / 5}\right)^{1.24}} \equiv K^{0.31} g(t) \cdots
$$

ここで, $K=K_{1} \gamma a^{3} D / k_{b} T r_{0}^{4}$ で， $K_{1}$ : 定数, $\gamma$ : 表面 張力, $a^{3}$ : 格子点体積, $D$ : 执散定数, $k_{b}$ : ボルツマン 定数, $T$ : 絶体温度, $r_{0}$ : 初期の粒径である. $k$ は電子 顕微鏡観察よりえられる定数で ${ }^{4)}, 0.15\left(750^{\circ} \mathrm{C}\right), 0.76$ $\left(850^{\circ} \mathrm{C}\right)$ である。われわれはこの (6) 式を用いて実験結 果を整理し， $\mathrm{nO}$ の焼結における雾囲気酸素圧の影響 について検討した。

$750^{\circ} \mathrm{C}$ における(6) 式の収縮率と $g(t)$ との関係を図一 7 に示した. いずれの場合もよい直線であらわされ，雾 囲気酸素圧が低くなるにつれて収縮率が大きくなり焼結 性がよくなることがわかる。 $850^{\circ} \mathrm{C}$ に掞ける(6) 式の収 縮率と $g(t)$ との関係を図-8 に示した。一般に初期赭 結での収縮率は 4〜5\% であると報告 ${ }^{7}$ されているが， 四からわかるよらにかなり収縮率の高いところまで直線 になり，酸素圧が低くなるにつれて収縮率が大きく焼結

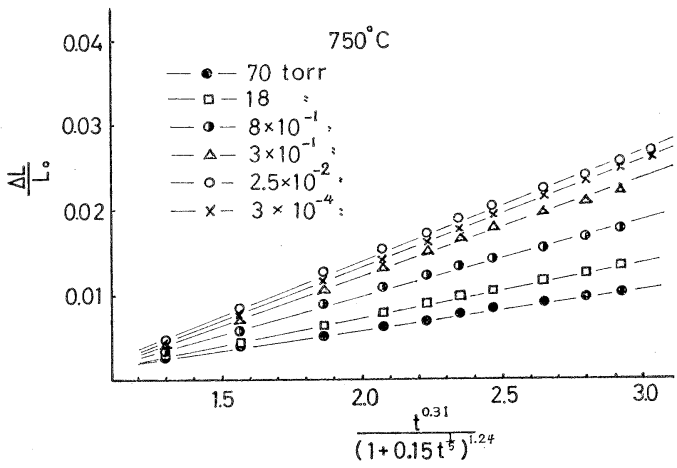

Fig. 7. Correlation between $\Delta L / L_{0}$ and $g(t)$ of equation (6) for $\mathrm{ZnO}$ compacts. 


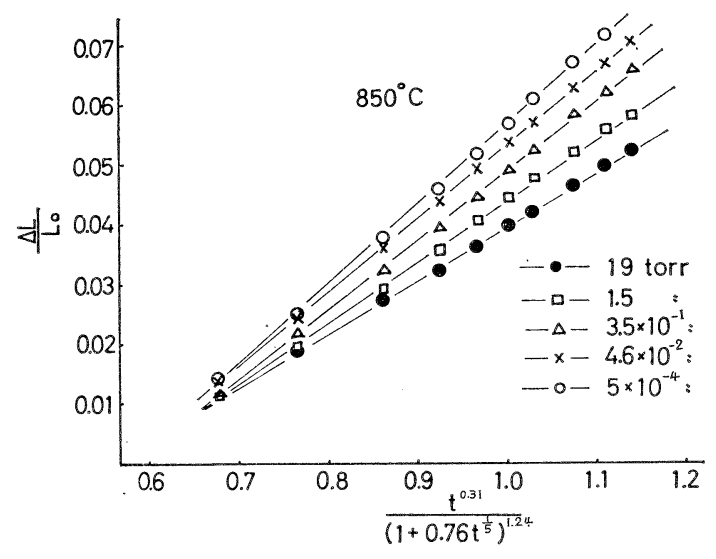

Fig. 8. Correlation between $\Delta L / L_{0}$ and $g(t)$ of equation (6) for $\mathrm{ZnO}$ compact.

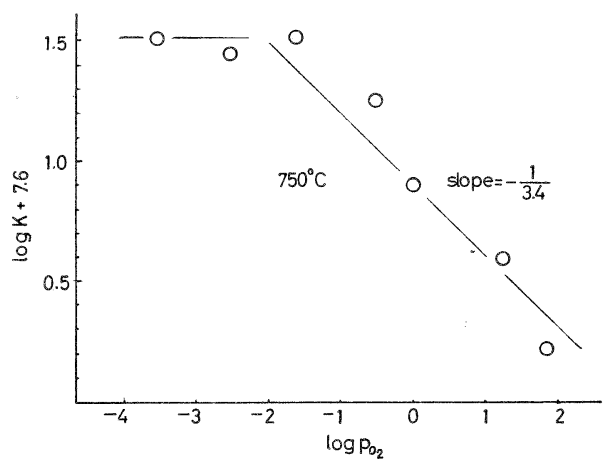

Fig. 9. Effect of oxygen pressure for sintering of $\mathrm{ZnO}$ compacts.

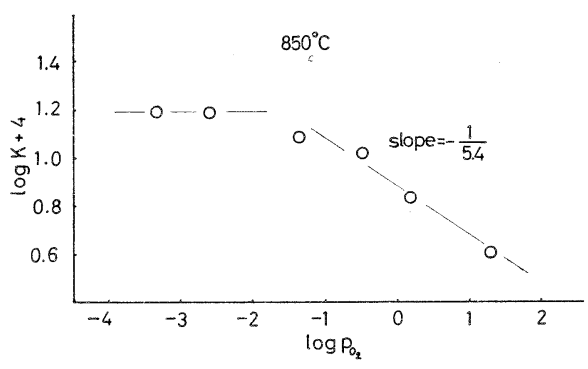

Fig. 10. Effect of oxygen pressure for sintering of $\mathrm{ZnO}$ compacts.

性がよくなることがわかる.これら直線の勾配は (6) 式 からわかるように焼結の速度定数 $K$ の 0.31 乗になる ので，幻配より $K$ が求をる. 一定温では $K$ の中に含 まれる表面張力, 拡散の活性化エネルギーなどのらち, 物質移動にあずかる格子間亜鉛イオンの濃度のみが雾囲 気酸素任に依存すると考光られるから，Kと雾囲気酸 素圧とをプロットすることによって，緒言でのべた焼結 の酸素圧依存性に関する情報をらることができる. 勾配 加らえられる速度定数 $K$ と酸素圧との関係を $750^{\circ}, 850$ ${ }^{\circ} \mathrm{C}$ について図 $-9,10$ に示した. $750^{\circ} \mathrm{C}$ の場合, $2.5 \times 10^{-2}$ torr 以上の高い酸素圧の領 域で酸素圧依存性があり，その部分の勾配を最小 2 乗法 で求めると $-1 / 3.4$ となる。つまり焼結性が酸素压の $-1 / 3.4$ 乗に比例して変化する. この值は電気伝導度に おけるー1/5 乗とは少し異なり（4）式で示されたー1/4 乘に近く，焼結の酸素圧依存性が (1) 式の解離で生成さ れる格子間覀鉛イオンの物質移動によって支配されるこ とを示すと考えられる.

$850^{\circ} \mathrm{C}$ では $3 \times 10^{-3}$ torr より高い酸素圧の領域で酸 素圧の $-1 / 5.4$ 乗に比例する.この值は (4) 式の $-1 / 4$ 乗より大きく, 電気伝導度の $-1 / 5$ 乗と (5) 式の $-1 / 6$ 乗とのほぽ中間の值であり, 焼結の酸素圧依存性が (1), (2) 式のらち (2) 式の方の寄与によって大きく影響さ れることを示している.

$750^{\circ}, 850^{\circ} \mathrm{C}$ いずれの場合も $2.5 \times 10^{-2}, 3 \times 10^{-3}$ torr より低い酸素圧の領域では焼結性が酸素圧に依存しなく なる.電気伝導度の測定結果が，これらの酸素圧領域に おいても酸素圧の - $1 / 5$ 乗に比例するので，格子間亜鉛 イオンの濃度も酸素圧の低下とともに増加するはずであ り，もしも $\mathrm{ZnO}$ の焼結が格子間覀鉛イオンの物質移動 により支配されるといら焼結の律速過程が変わらなけれ ば，焼結性も電気伝導度の場合と同じように酸素圧に依 存するであろら。われわれは次にのべるよらに $\mathrm{ZnO} の$ 焼結がどのように進行するかを考えた結果，焼結性が酸 素圧に依存しなくなる理由を焼結の律速過程が変わるた めではないかと推論した。

$\mathrm{ZnO}$ の焼結は（i）格子間亜鉛イオンが粒界拡散 ${ }^{4}$ (支 配的）および表面搪散とによって結晶粒界間のクビレ部 分に拡散する. (ii) 酸素はクビレ部分以外の表面で脱 離しガス中を拡散しで，クビレ 部分で $\mathrm{Zn}^{\circ}+\theta+1 / 2 \mathrm{O}_{2}$ $\rightarrow \mathrm{ZnO}$ または $\mathrm{Zn}^{\circ}+2 \ominus+1 / 2 \mathrm{O}_{2} \rightarrow \mathrm{ZnO}$ の反応により 格子形成を㧍こない,クビレ部分が成長して焼結が進行 する、酸素圧が高い領域では電気伝導度および焼結の酸 素圧依存性の結果から考えて（i）の過程が支配的に焼結 に関与する。酸素圧が低くなると焼結の酸素圧依存性が なくなるのは，雰囲気酸素圧が低くなればなるほど格子 間亜鉛イオンの濃度は，(1)，(2) 式の反応が右に進行し て増加するが，一方，逆にクビレ部分で格子形成にあず かる（ii）の過程がおそくなり，律速過程が (i) から (ii) に移行することが考えられる.このよらに考えてゆ くと $\mathrm{Gray}^{8)}$ が報告した $\mathrm{ZnO}$ の焼結性がわれわれとは 全く逆に，雰囲気酸素圧が高くなるほど良くなるという 実験結果が矛盾なく説明できる.

彼は炭酸覀鉛を低温，真空中で分解して $\mathrm{ZnO}$ をつく り，これを $175^{\circ} \mathrm{C}, 48$ 時間以上 $10^{-6}$ torr で処理，また は処理後の雾囲気圧が 24 時間放置後にも $10^{-5}$ torr よ りも高くならない程度にまで排気処理した $\mathrm{ZnO}$ 粉末試 料老用いて, $500^{\circ} \sim 800^{\circ} \mathrm{C}$ の範囲, 雾囲気酸素圧 $10^{-5}$, 
2.5, 380 torr について自由焼結をおこなっている.この ような排気処理のもとでは $\mathrm{ZnO} \rightarrow \mathrm{Zn}^{\circ}+\ominus+1 / 2 \mathrm{O}_{2}$ の 解離が右にかたよっており, 格子間亜鉛イオンの濃度が 十分高いと考えられる。したがって，(ii）でのべた格子 形成の過程が律速になり酸素圧が高いほど焼結性がよく なると推定される。

また Lee と Parravano ${ }^{9}$ は過剩の亜鉛蒸気と酸素と の反応から格子間平鉛イオンの過剩な $\mathrm{ZnO}$ を調製して $750^{\circ} \sim 900^{\circ} \mathrm{C}$ で焼結を叔こなっているが，その結果も酸 素雲囲気中の方がへリウム中より燒結性がよいと報告し ている。

(i) の過程のみが $\mathrm{ZnO}$ の焼結性を支配するなら，格 子間垔鉛イオンの濃度の大小が重要になるから酸素圧が 低いほど焼結性が良いことになり，(ii）の過程のみが支 配的な場合には酸素圧が高いほど焼結性がよくなるはず である. 恐らく本研究の零囲気酸素圧に依存しない領域 での焼結は，(i)，(ii）の兩方の過程がともに関与しつつ 焼結が進行してゆくと考えられる。

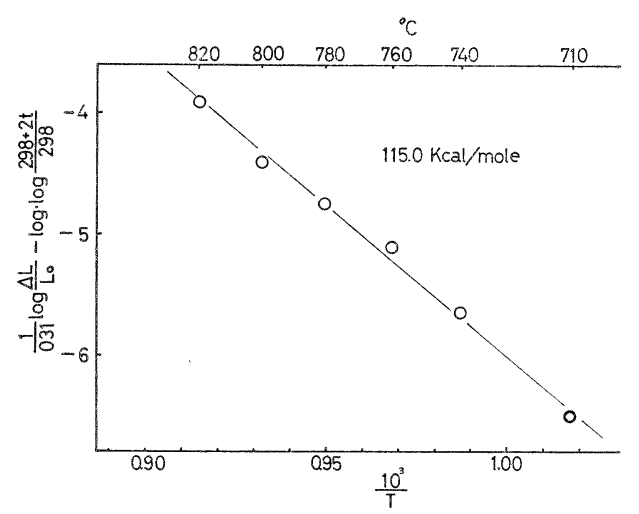

Fig. 11. Correlation between shrinkage and tempearature for $\mathrm{ZnO}$ compact at a constant rate of heating $\left(2^{\circ} \mathrm{C} / \mathrm{min}\right)$.

活性化エネルギーは焼結機構のめやすとなるので燒結 性が酸素圧に依存しない領域 $\left(10^{-4}\right.$ torr $\left.\mathrm{O}_{2}\right)$ でのそれ を昇温法 ${ }^{10)}\left(2^{\circ} \mathrm{C} / \mathrm{min}\right)$ によって求めてみた（図-11). そ の公配よりえられる活性化エネルギーは $115 \mathrm{kcal} / \mathrm{mol}$ で，酸素雰囲気中 ${ }^{4}$ あるいは空気中 ${ }^{10)}$ の焼結でえられた 值 $71.0 \sim 74.0 \mathrm{kcal} / \mathrm{mol}(\mathrm{ZnO}$ 中の $\mathrm{ZnO}$ の自己拡散 の值と一致 ${ }^{11)}$ ) とくらべて大きくなった. Tikkanen ${ }^{12)}$ はニッケルの焼結に捻いて，いくつかの機構がかさなっ て焼結が進行する場合にえられる見掛けの活性化エネル
ギーが大きくなると報告しているが，この結果が $\mathrm{ZnO}$ の場合にも適用できるのかもしれない。

雾囲気圧が小さくなった場合に, 蒸発一凝固による焼 結の可能性が考えられるが, Schäffer と Maywald ${ }^{13)}$ が $500^{\circ} \sim 900^{\circ} \mathrm{C}$ の範囲で測定した $\mathrm{ZnO}$ の蒸気圧のデーター から考えて, 本実験の条件下では無視できると考えられ る.

\section{4. 総括}

$\mathrm{ZnO}$ の燒結に打ける雾囲気酸素圧の影響を $750^{\circ}$ と $850^{\circ} \mathrm{C}$ とについて研究した. $750^{\circ} \mathrm{C}$ の場合, $2.5 \times 10^{-2}$ torrより高い酸素圧の領域で酸素圧依存性があり, 焼結 性が $P_{\mathrm{O}_{2}}{ }^{-1 / 3.4}$ に比例した. $850^{\circ} \mathrm{C}$ では $3 \times 10^{-3}$ torr よ り高い酸素圧の領域で $P_{\mathrm{O}_{2}}{ }^{-1 / 5.4}$ に比例することがわか った.これは $\mathrm{ZnO}$ の焼結性が格子間垔鉛イオンの桩散 に支配されることを示している。

低い䨌囲気酸素圧のもとでは $750^{\circ}, 850^{\circ} \mathrm{C}$ いずれの場 合も酸素圧依存性がなかった。この結果を燒結の律速段 階が，(i) 格子閒亜鉛イオンの桩散と，(ii) 格子間亜鉛 イオンと雲囲気酸素との格子形成の過程との両方がかさ なって䋆こるためと推論した。

\section{文献}

1) J.P. Roberts, J. Hutings, C. Wheeler, Trans. Brit. Ceram. Soc. 55, 75 (1956).

2) 小松和蔵, 宮本美貴夫, 藤田尚志, 守吉佑介, 窯協, 76 [12] 407 (1968).

3) H. Hv. Baumbach, C. Wagner, Z. Phys. Chem. B 29, 199 (1933); K. Hauffe, J. Block, Z. Phys. Chem. 196, 438 (1950).

4) Yusuke Moriyoshi, Wazo Komatsu, J. Am. Ceram. Soc. 53 [12] 671 (1970).

5）小松和蔵, 守吉佑介, 瀬戸直人, 䉑協, 77 [10] 349 (1969).

6) K. Hauffe, "Reaktionen in und an Festen Stoffen", Springer-Verlag, Berlin, (1966), s. 202.

7) R.L. Coble, J. Appl. Phys. 32, 534 (1954).

8) T.J. Gray, J. Am. Ceram. Soc. 37, 534 (1954).

9) V.J. Lee, G. Parravano, J. Appl. Phys. 30, 1735 (1959).

10) Yusuke Moriyoshi, Wazo Komatsu, Yogyo-KyokaiShi 79 [10] (1971).

11) E.A. Seco, W.J. Moore, J. Chem. Phys. 26, 942 (1962).

12) M. Tikkanen, Planseeber. Pulvermet. 11, 70 (1963).

13) H. Schäffer, H. Maywald, Z. Phys. Chem. B 244, 289 (1970).

$[6 / 7 / 1971$ 受付 $]$ 